\title{
CORRESPONDENCE
}

\section{Fission-track ages from the Precambrian of Shropshire}

SIR - Four samples of Longmyndian and Uriconian strata from south of Shrewsbury, England have been processed for apatite and/or zircon fission-track ages. The resultant ages illustrate how depth of burial may affect fission-track ages. The analytical procedures followed were as described in Naeser (1979).

Two samples (76Sh33 and 76Sh34) were collected from Uriconian rocks on Wart Hill (SO 34012847$)(325 \pm 7 \mathrm{Ma}$ ) and Longmyndian tuffs (SO 38604290$)(420 \pm 9 \mathrm{Ma})$ respectively, and are from west of the Church Stretton Fault Zone. The other two (B-1 and B-2) (526 $\pm 18 \mathrm{Ma}$ and $528 \pm 41 \mathrm{Ma}$ ) were two $6 \mathrm{~cm}$ thick bentonites $(9 \mathrm{~m}$ apart) collected from a $36 \mathrm{~m}$ sequence of shales and mudstones with numerous bentonites within the Stretton Shale Formation of the eastern Longmyndian, and are from east of the main Church Stretton Fault (F1). The locality (SO 4655 9373) was the site of a new reservoir and exposed previously unexamined strata from the lowest part of the Longmyndian. As may be seen from Table 1, the samples from west of the fault yield younger, that is reset, dates reflecting deeper burial and higher temperatures than those that have affected samples B-1 and B-2 from east of the fault. This is in accord with the fact that the western side has been upthrown relative to the eastern.

The concordance of the zircon-apatite pair for sample B-1 reflects either deep burial at a temperature above the annealing temperature of both minerals $\left(90^{\circ} \mathrm{C}\right.$ for apatite, $175-200^{\circ} \mathrm{C}$ for zircon), followed by uplift during late Cambrian times, circa $520 \mathrm{Ma}$, sufficiently rapid to set both the zircon and apatite clocks at essentially the same time. Alternatively, they may reflect primary ages indicating the time of deposition, although this seems unlikely. The bentonites which were numerous in this particular section, are the first to be recorded from the British Precambrian.

\section{Reference}

Naeser, C. W. 1979. Fission-track dating and geologic annealing of fission tracks. In Lectures in Isotope Geology (ed. E. Jager and J. C. Hunziker), pp. 154-69. New York: Springer-Verlag.

C. W. NAESER

U.S. Geological Survey

Denver Federal Center

Denver

Colorado 80225

U.S.A.

P. TOGHILL

Department of Extra Mural Studies

Birmingham University

P.O. Box 363

Birmingham B15 2TT

U.K.

R. J. ROSS Jr

Department of Geology

Colorado School of Mines

Golden

Colorado 80401

U.S.A.

10th August 1981 
Table 1. Fission-track ages from Longmyndian and Uriconian strata from the Anglo-Welsh Border region

\begin{tabular}{|c|c|c|c|c|c|c|c|c|}
\hline Sample & Mineral & $\begin{array}{c}\text { Number } \\
\text { of } \\
\text { grains } \\
\text { counted }\end{array}$ & $\mathbf{r}, \overline{\mathbf{s}}^{*}$ & $\begin{array}{c}\text { Spont. } \\
\text { tracks/ } \\
\mathrm{cm}^{2} \times 10^{6}\end{array}$ & $\begin{array}{l}\text { Induced } \\
\text { tracks/ } \\
\mathrm{cm}^{2} / 10^{6}\end{array}$ & $\begin{array}{c}\text { Neutrons/ } \\
\mathrm{cm}^{2} \\
\times 10^{15}\end{array}$ & $\underset{\mathrm{ppm}}{\mathrm{U}}$ & $\begin{array}{l}\text { Age } \pm \sigma \\
\text { yr } \times 10^{\circ}\end{array}$ \\
\hline \multicolumn{9}{|c|}{ West of Church Stretton Fault Zone } \\
\hline $\begin{array}{c}76 S h 33 \\
\text { DF-1723 }\end{array}$ & Zircon & 6 & $0.98(r)$ & $16.18(1177)$ & $14.33(521)$ & 4.93 & 80 & $325 \pm 7$ \\
\hline $\begin{array}{c}76 \mathrm{Sh} 34 \\
\mathrm{DF}-1717\end{array}$ & Zircon & 5 & $0.99(r)$ & $28.79(1483)$ & $19.92(513)$ & 5.02 & 110 & $420 \pm 9$ \\
\hline $\begin{array}{c}76 S h 34 \\
\text { DF- } 1724\end{array}$ & Apatite & 50 & $0.06(\bar{s})$ & $0.95(760)$ & $0.815(652)$ & 5.06 & 4.6 & $344 \pm 30$ \\
\hline \multicolumn{9}{|c|}{ East of Church Stretton Fault Zone } \\
\hline $\begin{array}{l}\text { B-1 } \\
\text { DF-1814 }\end{array}$ & Zircon & 6 & $0.96(r)$ & $26.24(1431)$ & $13.68(373)$ & 4.77 & 80 & $526 \pm 18$ \\
\hline $\begin{array}{l}\text { B-1 } \\
\text { DF-1789 }\end{array}$ & Apatite & 50 & $0.115(\bar{s})$ & $1.09(1007)$ & $0.127(118)$ & 1.02 & 3.6 & $501 \pm 64$ \\
\hline $\begin{array}{l}\text { B-2 } \\
\text { DF-1733 }\end{array}$ & Zircon & 2 & - & $\begin{array}{c}37.48(795) \\
-\end{array}$ & $19.89(211)$ & 4.85 & 120 & $528 \pm 41$ \\
\hline
\end{tabular}

